\title{
Influence Of Price Discount, In-Store Display, And Shopping Lifestyle On Impulse Buying At Umama Gallery Sidoarjo
}

OPEN ACCESS ISSN 2528-4649 (online) ISSN 2338-4409 (print)

Reviewed by: Prof. Dr. Anton Agus Setyawan, S.E., M.Si.

${ }^{*}$ Correspondence: Meizar Nur Hidayah meizarnh15@gmail.com Received: December 30, 2020 Accepted: February 20, 2021 diterima Published: March 31, 2021 JBMP: Jurnal Bisnis, Manajemen dan Perbankan. Vol: $7 /$ No. 1 doi: 10.21070/jbmp.v7i1.1338
Meizar Nur Hidayah ${ }^{1}$, Dewi Komala Sari²

Faculty of Business, Law, and Social Sciences, University of Muhammadiyah Sidoarjo, Indonesia

This study aims to determine the effect of price discount, in-store display, and shopping lifestyle on impulse buying at Umama Gallery Sidoarjo. The method used in this research is a quantitative approach. Sampling was done by using non-probability sampling method with purposive sampling type with a total of 100 respondents who had visited and bought products at Umama Gallery Sidoarjo. The data analysis technique in this study uses multiple linear regression using the IBM SPSS Statistics version 21 program. The results show that price discount have an influence on impulse buying, in-store display have an influence on impulse buying, shopping lifestyle has an influence on impulse buying, and price discount, in-store display, and shopping lifestyle have a simultaneous influence on impulse buying.

Keywords: Price Discount, In-Store Display, Shopping Lifestyle, Impulse Buying 


\section{INTRODUCTION}

In this modern era, the rapid development of retail business in Indonesia encourages the emergence of increasingly competitive business groups and business activities demanding every company to pay attention to the needs and wants of consumers and meet consumer expectations. Consumer behavior is the thing that underlies the consumer to make a purchase decision. In relation to marketing activities, consumer behavior and factors that affect it are of concern to companies including retail companies.

One of the fastest growing business sectors is fashion products. Fashion changes every year. Aspects of fashion touch in everyday life and affect a person. Similarly, every woman wants to look attractive, so fashion products and women are two things that can not be separated from each other because fashion products affect physical appearance and lifestyle. Similarly, with the Muslim fashion trend, in today's modern era Muslim fashion, especially hijab, also develops every year by not violating islamic religious rules. Now hijab is one of the fashions that are in demand, especially by Muslim women. (Febriani \& Purwanto, 2019).

The development of modern retail business has an impact on the behavior of consumers who originally shopped with planned intentions to be unplanned. (Pontoh et al., 2017). According to Mowen \& Minor in Zayusman \& Septrizola (2019) Impulsive buying is the act of buying that is done without having any previous problems or previously formed buying intentions. In addition, according to Kacen and Lee in Artana et al. (2019) Impulse Buying is an act of pre-planned product purchase that occurs as a result of the stimulus received and this action is immediately decided immediately.

The results of research in Jakarta cited by Arfianti in Widiyati \& Ghozi (2018) show that impulse buying in modern retail reaches $44 \%$ of the number of items purchased by consumers on weekdays. On Saturdays and Sundays the number increased to $61 \%$. This is supported by a survey conducted by AC Nielsen (in figure 1), showing that about $85 \%$ of purchases made in the city of Surabaya are impulse buying purchases, only $15 \%$ of consumers plan their purchases. (Adiputra, 2015).

\section{[Figure 1 about here.]}

With the increasing number of retail industries, especially in the Muslim fashion sector, marketers must understand the needs and wants of consumers and create strategies that can retain customers and attract new customers, among others, by arranging a good and attractive in-store display. According to Loudon and Bitta in Sari (2018) attractive displays can affect impulse buying. Attractive displays can also change the boring atmosphere of the store to not only more attractive but also increase sales, According to Foster in Sonata (2019) in-

store display is an effort to encourage consumer attention and interest in the store or goods and encourage the desire to buy through direct vision appeal or commonly called direct visual appeal. Alma in Pontoh et al. (2017) mentions the meaning of display which is the desire to buy something, which is not driven by a person, but driven by attractiveness, or by vision or by other feelings.

Conducting a number of sales promotions such as price, it is expected that later the strategy can increase unplanned purchases in retail stores. Price discount has a very important role in influencing consumer decisions in buying products, so it is very important to determine the marketing success of a product. Peter and Olson in Sonata (2019) define price discount as a price discount that involves a long-term plan to systematically lower prices after introducing high-priced products. While according to Tjiptono in Artana et al. (2019) discounts are one type of sales promotion. A discount is a product deduction from a normal price within a certain period. Sonata (2019) said that attractive promotions conducted by a company, one of which is price discount can drive impulse buying decisions are increasing.

In addition, several factors that can influence purchasing decisions are psychological factors, consumer characteristics, and also the state of the consumer economy. Economic development causes a change inone's lifestyle. According to Levy \& Weitz in Fauziyyah \& Oktafani (2018) shopping lifestyle is a lifestyle that refers to how a person lives, how they spend their time, money, purchasing activities, attitudes and opinions about the world in which they live. A person's lifestyle in spending the money makes a new social status, nature and characteristics for an individual. Lifestyle is also used market segmentation because it has provided a view of daily life from consumers at large. The economic condition of each individual makes the consumer consumptive, so when looking at an item that he considers attractive will be purchased even at a fairly high price. One of the activities related to lifestyle is shopping. Nowadays, routine shopping is a person's lifestyle and has periodic planning. Shopping activities are not only used to find a needed item but also used as entertainment or to eliminate boredom. Shopping lifestyle reflects one's choices or ways of spending time and money. (Fauziyyah \& Oktafani, 2018). Shopping lifestyle describes a person's activities in spending time and money. With the availability of time customers will have a lot of time to shop with their money and will have high purchasing power so that impulse buying rates will also increase. This is evidenced in Zayusman \& Septrizola (2019) which mentions that shopping lifestyle affects impulse buying.

Seeing the rapid development of Muslim fashion today, many fashion companies began to appear to offer their products with a variety of attractive models and adjust to the current trends but still in accordance with Islamic sharia. One of the Muslim fashion companies that began to be known and has its own characteristics is Umama Scarf which is a hijab brand that has a commitment to make Muslim women in Indonesia have characteristics in muslim dress in accordance with Islamic law and inspire dress for other Muslim women. Umama Scarf has a product with quality materials and equipped with a variety of motif designs that are up to date and beautiful but with a price that is classified as affordable so as to make this brand quite well known in all circles, especially among the middle age. 
In practice, Umama Gallery also conducts various strategies to attract consumers and also retain customers. One of the strategies that has been done is to do a discount for some of its products at certain times, for example at the time of Eid al-Fitr, Christmas or at the end of the year. In addition, price discount are also given to customers who have a member card or at the time of buying a product in large quantities that have been determined. Umama Gallery has also implemented a room arrangement (in-store display) that is quite good by arranging products according to the type and color of the product, so that consumers can be easier when looking for the desired product. Umama gallery also arranges shelves in such a way as to make it easier for consumers to get around and in and out of stores.

In connection with the retail strategy that attracts consumer buying interest, impulse buying behavior is something that appeals to retail companies. Fashion products, especially clothing and hijab is an item that is used daily so that it allows to be purchased impulsively (without prior planning). With this phenomenon of impulsive purchases, it can be used as an opportunity by retailers so as to give a positive influence to the company. Impulse buying behavior can help retailers develop sales strategies to increase turnover earned by retailers.

In a study conducted by Melina \& Kadafi (2017) stated that price discount and in-store display affect $40.20 \%$ on impulse buying. In line with research conducted by Sonata (2019) which states that variable price discount and variable instore display can affect impulse buying by $46 \%$. In Artana et al., (2019) also stated that display product variables have a positive and significant influence on impulse buying as well as variable price discount has a positive and significant influence on impulse buying. While in the study conducted by Wilujeng (2017) stated that the price discount partially has no effect on impulse buying. In addition, research conducted by Haironi (2018) tated that in-store display variables do not significantly affect impulse buying. In Fauziyyah \& Oktafani (2018) stated that shopping lifestyle has an effect of $70.38 \%$ on impulse buying. In line with research conducted by Zayusman \& Septrizola (2019) which states that shopping lifestyle has a significant effect on impulse buying. In also stated the same thing that shopping lifestyle variables significantly positively affect impulse buying. While in the research conducted by Irawan, Arifin, dan Basalamah (2020) stated that shopping lifestyle has no significant effect on impulse buying.

Based on the research review above shows inconsistencies in the results of previous research on the influence of price discount, in-store display and shopping lifestyle on impulse buying. So it takes re-research or re-verification to know that the variables to be studied have an influence or not.

In this case, researchers are also interested and want to examine more deeply about the influence of price discount, instore dislpay and shopping lifestyle on impulse buying on different objects, namely at Umama Gallery Sidoarjo. So the title that will be raised is "Influence of Price Discount, In-Store Display and Shopping Lifestyle On Impulse Buying At Umama Gallery Sidoarjo".

\section{Theoretical Studies}

\section{Marketing Management}

Marketing as a process of how to identify the needs of consumers then produce the goods or services that consumers need and convince consumers that they need the goods or services, so that there is a transaction or exchange between the manufacturer and the consumer. Such exchanges or transactions cause consumers to obtain goods or services that can benefit them, and consumers provide some rewards in the form of money or other to the manufacturer. (Sumarwan, 2015)

\section{Retail}

Retailing is all activities of selling goods and services directly to the end consumer for personal and household use, not for business purposes. (Tjiptono, 2015)

\section{Price Discount}

A discount is a discount given by the seller to the buyer in recognition of certain activities that the buyer undertakes, such as paying bills faster, buying in bulk, or buying in the off-season or peak demand period. (Tjiptono, 2015)

Indicators of Price Discount according to Wahyudi in Artana et al. (2019) include:

Discount Frequency: The discount frequency refers to how often marketers in a retail outlet discount the products they offer.

Discount Amount: The amount of discount is how much discount is offered by marketers to the products offered to their consumers, which can be seen from the percentage for example $30 \%, 50 \%$ etc.

Discount Time: The time of discounting refers to whenever the marketer chooses to discount the products offered to consumers.

\section{In-Store Display}

Foster in Sonata (2019) said In-Store Display is an effort to encourage consumer attention and interest in the store or goods and encourage the desire to buy through direct vision appeal or commonly called direct visual appeal.

Utami (2017) mentioned several things to consider in the preparation of retail store layout, namely:

Directing consumers around the store

Retail store management must arrange the flow or route that will be passed by the consumer from the beginning when the consumer enters the store door until the consumer exits the store door.

Make it easier for consumers to get around the store

Retail store management needs to organize the store space by arranging the arrangement of merchandise so as to provide a corridor of the road to consumers. Consumer road corridors should pay attention to the distance between consumers and the display of goods in the store. When the conditions are crowded visitors then the road corridor should be able to accommodate at least two consumers who are at the same location point at the same time. This distance gives the opportunity for consumers to cross paths with each other while traveling around or at the time 
of stopping to check and pick up the goods to be purchased.

Make it easier for consumers to find goods

A good retail store space arrangement should be able to facilitate consumers to easily see and find the items they need and want. The different formats of retail stores require different spatial planning strategies with regard to efforts to facilitate consumers in finding the goods they need and want.

\section{Shopping Lifestyle}

Darma \& Japarianto stated that Shopping lifestyle describes one's activities in spending time and money. With the availability of time customers will have a lot of time to shop and with the money will have a high purchasing power. Shopping lifestyle describes a person's activities in spending time and money. With the availability of time customers will have a lot of time to shop and with the money will have a high purchasing power. (Zayusman \& Septrizola, 2019).

Shopping lifestyle is stated in several indicators to know the relationship between shopping lifestyle to impulsive purchases, according to Park and Sullivan in Gunawan \& Sitinjak (2019) such indicators include:

Have a fun experience

Fun activities

Shop when bored

There is a new Model

Means of sad removal

Shopping obsessed

Shopping to waste time.

\section{Impulse Buying}

Mowen \& Minor in Zayusman \& Septrizola (2019) defines impulsive purchases as buying actions made without having any prior problems or buying intentions formed before entering the store.

Pontoh et al. (2017) states that indicators for measuring impulse buying behavior are as follows:

Unplanned purchase

Purchase without thinking as a result of

Purchase affected emotional state

Purchases are influenced by attractive offers

\section{Conceptual Framework}

\section{[Figure 2 about here.]}

Description:

$\mathrm{X} 1$ : Price Discount

X2 : In-Store Display

X3 : Shopping Lifestyle

$\mathrm{Y}$ : Impulse Buying

$\mathrm{H} 1$ : effect of $\mathrm{X} 1$ to $\mathrm{Y}$

$\mathrm{H} 2$ : effect of $\mathrm{X} 2$ to $\mathrm{Y}$

$\mathrm{H} 3$ : effect of $\mathrm{X} 3$ to $\mathrm{Y}$

$\mathrm{H} 4$ : simultaneous influence of $\mathrm{X} 1, \mathrm{X} 2$, and $\mathrm{X} 3$ on $\mathrm{Y}$

\section{Hipotesis}

H1: Price Discount has an influence on Impulse Buying.

$\mathrm{H} 2$ : Display Product has an influence on Impulse Buying.

H3: Shopping Lifestyle has an influence on Impulse Buying.

H4: Price Discount, Display Product and Shopping Lifestyle have simultaneous influence on Impulse Buying.

\section{METHOD (FOR RESEARCH ARTICLE)}

\section{Research Approach}

This research uses quantitative research method, where quantitative method is to use statistical aid to help research in the calculation of figures to analyze the data obtained. (Sugiyono, 2017)

\section{Research Location}

This research was conducted on residents of Sidoarjo, East Java, Indonesia.

\section{Reasearch Design}

The design of the research used is associative research with a type of causal relationship because it explains the existence of causal relationships. So in this study there were independent variables (variables that affect) and dependent variables (affected variables).

This type of research is included in the type of survey research because it takes samples from a population and uses questionnaires as a data collection tool using Google form that is distributed to umama Gallery Sidoarjo consumers who have visited and purchased products at umama Gallery Sidoarjo.

\section{Population and Samples Population}

Population is a generalized area consisting of objects / subjects that have certain qualities and characteristics set by researchers to be studied and then drawn conclusions.(Sugiyono, 2017).

The population targeted in this study is sidoarjo residents who have visited Umama Gallery Sidoarjo.

Sample

Samples are part of the number of characteristics that the population has. (Sugiyono, 2017). The sample in this study uses Non Probability Sampling method which is a sampling technique that does not provide the same opportunities for each element or member of the population to be selected into a sample. Then, from various types of Non Probability Sampling techniques available, in this study using Purposive Sampling technique where in determining samples with certain considerations and have the following criteria:

Respondents who have visited and purchased products at Umama Gallery Sidoarjo. This is because it makes it easier for researchers to find respondents in the study.

Respondents who are 17 years of age or older, this is because the respondent has sufficient knowledge in filling out questionnaires.

Because of the unknown or unlimited population, sampling 
is done using Supranto's formula (2016):

$$
\mathrm{n}=\left(\frac{\mathrm{z}_{\alpha / 2} \sigma}{\varepsilon}\right)^{2}
$$

Description :

$\mathrm{n} \quad=$ Number of samples

$z_{\alpha / 2}=$ value of normal distribution table over trust

$$
95 \%
$$

$=1,96$

$\sigma=$ standard deviation $25 \%=0,25$

$\varepsilon=$ error $5 \%=0,05$

Through the above formula, the number of samples to be taken is:

$$
\begin{aligned}
& \mathrm{n}=\left(\frac{\mathrm{z}_{\alpha / 2} \sigma}{\varepsilon}\right)^{2} \\
& \mathrm{n}=\left(\frac{1,96 \cdot 0,25}{0,05}\right)^{2} \\
& \mathrm{n}=96,04
\end{aligned}
$$

Based on the formula, the $\mathrm{n}$ obtained is 96.04 people and rounded up to 100 people. So the number of samples in this study as many as 100 consumers Umama Gallery Sidoarjo.

\section{Types and Data Sources \\ Data Types}

The type of data in this study is quantitative data because the research data in the form of figures and analysis using statistics and can be drawn conclusions with the problems studied.(Sugiyono, 2017)

\section{Data Sources}

The data sources used in this study are primary and secondary data sources.

The primary data source is the data source that directly provides data to the data collector.(Sugiyono, 2017). The primary data in this study is a questionnaire that will be filled out by respondents who have met the criteria to be the sample mentioned earlier.

Secondary data source is a source that does not directly provide data to the data collector.(Sugiyono, 2017). Secondary sources in this study are journals and previous research related to this study.

\section{Data Collection Techniques}

The data collection technique used in this study is a survey method by distributing questionnaires. Survey method used to obtain data from a certain natural place (not artificial) by doing the act in the form of questionnaire distribution. Questionnaire is a data collection technique that is done by giving a set of questions or written statements to respondents to answer.(Sugiyono, 2017).

This questionnaire uses an open question given to consumers through the google form by asking respondents to choose one of the answers that have been available in each question. The data scale used in this study is the likert scale. The Likert scale is used to measure the attitudes, opinions, and perceptions of a person or group of people about social phenomena.(Sugiyono, 2017).

\section{RESULTS AND DISCUSSION}

\section{Validity Test}

The item validity test in this study used Pearson's correlation method, which is to correlate the item score with each variable item, then the significance test was conducted with criteria using $r$ table at a significance level of 0.05 with a 2-sided test. If the value of $r$ count $>r$ table then the item can be declared valid. However if the $r$ count $<r$ table then the item is declared invalid.(Priyatno, 2018). In this study, validity testing was using the IBM SPSS Statistics Version 21 program.

\section{Price Discount}

[Table 1 about here.]

Based on table 1 above, it can be seen that all statement items for variable price discount have a valid status, because the value of $r$ calculate $>r$ table is 0.195 .

\section{In-Store Display}

[Table 2 about here.]

Based on table 2 above, it can be seen that all statement items for variable price discount have a valid status, because the value of $r$ calculate $>r$ table is 0.195 .

\section{Shopping Lifestyle}

[Table 3 about here.]

Based on table 3 above, it can be seen that all statement items for variable price discount have a valid status, because the value of $r$ calculate $>r$ table is 0.195 .

\section{Impulse Buying}

[Table 4 about here.]

Based on table 4 above, it can be seen that all statement items for variable price discount have a valid status, because the value of $r$ calculate $>r$ table is 0.195 .

\section{Reliability Test}

The method used to measure the range scale (in this study 
using the likert scale) in this study was Cronbach Alpha. The item entered in the test is a valid item only (in the validity test) and to determine whether the instrument is reliable or not, using the 0.6 limit. Reliability of less than 0.6 is less good, while 0.7 is acceptable and above 0.8 is good.(Priyatno, 2018). In this study, reliability testing was using ibm SPSS Statistics Version 21 program.

[Table 5 about here.]

Based on table 5 above, it can be seen that the price discount indicator is reliable with cronbach's alpha of $0.707>0.60$ as the limit value which means that the price discount indicator has met the reliability test. The results of the in-store display reliabel study with cronbach's alpha of $0.662>0.60$ as the limit value means that the in-store display indicator has met the reliability test. The results of the study of shopping lifestyle reliable with cronbach's alpha of $0.810>0.60$ as the limit value which means the shopping lifestyle indicator has met the reliability test. Similarly, the variable impulse buying indicator is reliable with cronbach's alpha of $0.693>0.60$ as the limit value which means the impulse buying indicator has met the reliability test.

\section{Normality Test}

The normality test method used in this study uses a graphing method, namely by looking at the spread of data at diagonal sources on the Normal P-P Plot of regression standardized residual graph.

\section{[Figure 3 about here.]}

Based on the picture above shows that the spread of data forms points close to the diagonal line, it can be concluded that the data is normally distributed.

\section{Heteroskedastisity Test}

The heteroskedastisity test method used in this study was to look at the pattern of dots on the scatterplots chart between standardized predicted value (ZPRED) and studentized residual (SRESID). If there are certain patterns such as dots that form a certain pattern that is regular then heteroskedastisitas occur, but if there is no clear pattern such as dots spreading above and below the number 0 on the $\mathrm{Y}$ axis then there is no heteroskedastisitas.

\section{[Figure 4 about here.]}

Based on the picture above shows that the dots spread randomly, do not form a certain pattern that is clear and scattered both above and below zeros on the $\mathrm{Y}$ axis.

\section{Multicolonierity Test}

The multicolonierity test method used in this study is by looking at tolerance and inflation factor (VIF) values in the regression model. A regression model is said to be free of multicolonierity if it has a VIF value (Variance Inflation Factor) less than 10 and has a Tolerance number of more than 0.1 .

\section{[Table 6 about here.]}

Based on table 6 above, it can be seen that all variables have a VIF value of less than 10 and have a Tolerance value of more than 0.1 . This indicates that there is no multicolonierity between variables.

\section{Multiple Linear Regression Analysis}

Based on the processed data that has been done using IBM SPSS Statistics version 21program, it can be known the relationship model of this multiple linear regression can be seen from the following table:

[Table 7 about here.]

Based on the calculation results obtained in table 7 above, it can be made the equation of multiple linear regression models as follows:

$$
\mathrm{Y}=-1,358+0,569 \mathrm{X}_{1}+0,294 \mathrm{X}_{2}+0,183 \mathrm{X}_{3}
$$

The equation can be interpreted that:

Negative constant value indicates the negative influence of variable price discount, (X1),in-store display (X2), and shopping lifestyle (X3). If the variable price discount (X1), instore display X2), and shopping lifestyle (X3) are down or have no effect in one unit, then the impulse buying variable will drop.

The coefficient value of 0.569 indicates the amount of price discount (X1) against impulse buying (Y) marked positive or unidirectional. In other words, if the price discount (X1) increases by 1 unit, it will cause an increase in impulse buying value $(\mathrm{Y})$ of 0.569 units assuming other variables remain or are constant.

The coefficient value of 0.294 indicates the magnitude of the in-store display (X2) against impulse buying(Y) marked positive or unidirectional. In other words, if the in-store display (X2) increases by 1 unit it will cause an increase in impulse buying $(\mathrm{Y})$ value of 0.294 units assuming other variables remain or are constant.

The coefficient value of 0.183 indicates the magnitude of the shopping lifestyle (X3) against impulse buying (Y) marked positive or in the same direction. In other words, if shopping lifestyle (X3) increases by 1 unit it will cause an increase in impulse buying value $(\mathrm{Y})$ of 0.183 units assuming other variables remain or constant. 


\section{Correlation Coefficient Test (R)}

[Table 8 about here.]

Based on table 8 above obtained correlation value (R) of 0.942 or $94.2 \%$ which shows that there is a very strong relationship between price discount (X1), in-store display (X2), and shopping lifestyle (X3) to impulse buying (Y).

\section{Coefficient Determination Test $\left(\mathbf{R}^{2}\right)$}

[Table 9 about here.]

Based on table 9 above obtained determination value 0.888 or $88.8 \%$ which indicates that variable price discount (X1), instore display (X2), and shopping lifestyle (X3) together (simultaneously) affect impulse buying (Y) by $88.8 \%$. While the remaining $11.2 \%$ was caused by other variables not mentioned in this study.

\section{T Test (Partial)}

[Table 10 about here.]

Based on table 10 above so that it can be interpreted as follows: From the calculation of $\mathrm{t}$ test obtained $\mathrm{t}$ calculate price discount of 7,381 with a significance value of 0.000 . Because the value of $t$ calculate $>t$ table $(7,381>1,985)$ and obtained significance value $<0.05(0,000<0,05)$ so it can be concluded that variable price discount has a positive influence on impulse buying variables.

From the calculation of $\mathrm{t}$ test obtained $\mathrm{t}$ count in-store display of 3,171 with a significance value of 0.002 . Because the value of $t$ count $>t$ table $(3,171>1,985)$ and obtained significance value $<0.05(0.002<0,05)$ so it can be concluded that in-store display variables have a positive influence on impulse buying variables.

From the calculation of $t$ test obtained $t$ calculate shopping lifestyle of 4,358 with a significance value of 0.000 .

Because the value of $t$ calculate $>t$ table $(4,358>1,985)$ and obtained significance value $<0.05(0,000<0,05)$ so it can be concluded that the variable shopping lifestyle has a positive influence on impulse buying variables.

\section{F Test (Simultaneous)}

[Table 11 about here.]
Based on table 11 above, it can be seen that the calculated $\mathrm{f}$ is 253,868 greater than the table $\mathrm{f}(253,868>2.70)$ with a significance value of $<0.05(0.000<0.05)$ so that it can be concluded that variable price discount, in-store display, and shopping lifestyle have a simultaneous influence on impulse buying variables.

\section{DISCUSSION}

This study tested whether price discount, in-store display, and shopping lifestyle have an influence on impulse buying. Based on empirical testing that has been conducted against hypotheses in the study, the results show the following: Price Discount has an influence on Impulse Buying.

Based on the results of hypothesis testing proves that price discount has an influence on impulse buying. . This indicates that consumers will be more interested in shopping if customers who have a member card will be given a special discount, in addition to the large percentage of discounts offered will also attract customers to shop more. Consumers will also be more eager to shop if retail stores often hold discounts, especially at certain times (Eid al-Fitr, Christmas, End of year), so that it can increase unplanned purchases made by consumers.

This is in accordance with the theory expressed by Sumarwan in Sari (2018) stated that the display about the discounted prices displayed and striking will certainly attract the attention of consumers. By looking at the display can evoke an urgent feeling to meet their needs and buy the promoted product. In line with the research conducted by Sonata (2019) which states that price discount positively affect impulse buying. Another study that states the same thing is Artana et al. (2019) which states that price discount has a significant positive influence on impulse buying.

In-Store Display has an influence on Impulse Buying.

Based on the results of hypothesis testing proves that instore display has an influence on impulse buying. A clear and interesting store flow will also increase the interest of consumers to visit the store so that the rate of unplanned purchases made by consumers will also increase.

This is in accordance with the theory expressed by Loudon and Bitta in hat attractive displays can affect impulse buying. Attractive displays can also change the boring atmosphere of the store to not only be more attractive but also increase sales. In line with research conducted by Melina \& Kadafi (2017) which stated that in-store display has a positive and significant effect on impulse buying. Another supportive research is research conducted by Sonata (2019) which states that in-store display variables can affect impulse buying variables.

Shopping Lifestyle has an influence on Impulse Buying.

Based on the results of the hypothesis testing, it is believed that shopping lifestyle has an influence on impulse buying. This shows that shopping is a fun activity and provides a pleasant experience for consumers, so shopping becomes one of the options to improve the mood. In addition, when there are new fashion items, feel bored with daily activities, or when not doing anything and just to spend free time consumers will tend to do shopping activities. Not a few consumers who love shopping and become obsessed with it especially when it is sad. So with 
this will increase unplanned purchases made by consumers.

This is in accordance with the theory expressed by Levy \& Weitz in Fauziyyah \& Oktafani (2018) hat shopping lifestyle is a lifestyle that refers to how a person lives, how they spend their time, money, purchasing activities, attitudes and opinions about the world in which they live. A person's lifestyle in spending the money makes a new social status, nature and characteristics for an individual. With the availability of time customers will have a lot of time to shop with their money and will have high purchasing power so that impulse buying rates will also increase. In line with the research conducted by Gunawan \& Sitinjak (2018) which states that shopping lifestyle ( shopping lifestyle) has a positive and significant effect on impulsive purchases (impulse buying). In addition, another study conducted by Zayusman \& Septrizola (2019) also stated the same thing that shopping lifestyle has a significant effect on impulse buying.

Price Discount, In-Store Display, and Shopping Lifestyle have simultaneous influence on Impulse Buying.

Based on the results of hypothesis testing shows that price discount, in-store display, and shopping lifestyle together (simultaneously) have a positive influence on impulse buying. Thus it can be stated that any increase in the value of variable price discount, in store display and shopping lifestyle together will increase the value of impulse buying.

The relationship between free variables and impulse buying variables in this study is very strong and in the direction between free variables that include price discount, in store display and shopping lifestyle on bound variables namely impulse buying. That is, if the free variables that include price discount, in store display and shopping lifestyle are improved, then the bound variable that is impulse buying will increase, and vice versa. 


\section{REFERENCES}

Adiputra, E. (2015). Perilaku Pembelian Tidak Terencana (Impulse Buying) Di Pusat Perbenjaan Modern Di Surabaya. AnNisbah: Jurnal Ekonomi Syariah, Vol.01(No.02), 155-180. https://doi.org/10.21274/an.2015.1.2.155-180

Artana, I. P. W., Wisesa, I. G. B. S., Setiawan, I. K., Utami, N. L. P. M. P., Yasa, N. N. K., \& Jatra, M. (2019). Pengaruh store Atmosphere, Display poduct, dan pice Discount terhadap Impulse Buying. E-Jurnal Ekonomi Dan Bisnis Universitas Udayana, Vol.8(No.4), 369-394.

Deviana D, N. P. S., \& Kt.Giantari, I. G. A. (2016). Pengaruh Shopping Lifestyle Dan Fashion Involvement Terhadap Impulse Buying Behaviour Masyarakat Di Kota Denpasar. E-Jurnal Manajemen Universitas Udayana, Vol.5(No.8), 5264-5273.

Fauziyyah, A. N., \& Oktafani, F. (2018). Pengaruh Shopping Lifestyle Dan Fashion Involvement Terhadap Impulse Buying Behavior (Studi pada Masyarakat Kota Bandung). JURISMA: Jurnal Riset Bisnis \& Manajemen, Vol.8(No.1), 1-14. https://doi.org/10.34010/jurisma.v8i1.994

Febriani, S. F., \& Purwanto, N. (2019). Pengaruh Shopping Lifestyle Dan Fashion Involvement Terhadap Impulse Buying Pada Konsumen Hijab Butik Rabbani Jombang. JMD: Jurnal Riset Manajemen \& Bisnis Dewantara, Vol.2(No.2), 53-62. https://doi.org/10.26533/jmd.v2i2.372

Gunawan, G. T., \& Sitinjak, T. (2018). Pengaruh Keterlibatan Fashion Dan Gaya Hidup Berbelanja Terhadap Pembelian Impulsif (Studi Terhadap Remaja Dan Pemuda Dki Jakarta). Jurnal Manajemen, Vol.7(No.2), 109-123.

Haironi, M. (2018). Pengaruh Discount, Bonus Pack, Dan In-Store Display Terhadap Impulse Buying Produk Obat Nyamuk HIT di Pamella Swalayan Yogyakarta. Journal Ekobis Dewantara, 1(3), 118-126.

Irawan, D. O., Arifin, R., \& Basalamah, M. R. (2020). Pengaruh Shopping Lifestyle, Discount, Fashion Involvement, Hedonic Shopping Motivation, dan Promosi Penjualan Terhadap Impulse buying (Studi Kasus Pada Mahasiswi Yang Pernah Berkunjung Ke Center Point Di Mall Olympic Garden Malang). E-Jurnal Riset Manajemen Prodi Manajemen Fakultas Ekonomi Dan Bisnis Unisma, Vol.09(No.04), 152-167.

Melina, \& Kadafi, M. A. (2017). Pengaruh price discount dan in-store display terhadap impulse buying. Forum Ekonomi, Vol.19(No.2), 201-209. http://journal.feb.unmul.ac.id/index.php/FORUMEKONOMI

Pontoh, M. E., Moniharapon, S., \& Roring, F. (2017). Pengaruh Display Produk dan Store Atmosphere Terhadap Impulse Bulying pada Konsumen Matahari department Store Mega Mall Manado. Jurnal Emba, Vol.5(No.2), 1823-1833. https://doi.org/10.1063/1.4740043

Priyatno, D. (2018). SPSS Panduan Mudah Olah Data Bagi Mahasiswa \& Umum. Penerbit ANDI.

Sari, D. K. (2018). Peran In Store Stimuli Dalam Customer Impulse Buying Serta Implikasinya Terhadap Strategi Pemasaran Pada Minimarket. Eksis: Jurnal Riset Ekonomi Dan Bisnis, Vol.13(No.2), 101-110.

Sonata, I. (2019). Pengaruh Price Discount Dan Store Atmosphere Terhadap Keputusan Impulse Buying Pada. Jurnal Riset Manajemen \& Bisnis (JRMB), Vol.4(No.1), 46-53.

Sugiyono. (2017). Metode Penelitian Kuantitatif, Kualitatif, dan R\&D. Alfabeta.

Sumarwan, U. (2015). Perilaku Konsumen Teori dan Penerapannyadalam Pemasaran.

Supranto, J. (2016). Statistik Teori \& Aplikasi (8(2)). Penerbit Erlangga.

Tjiptono, F. (2015). Strategi Pemasaran (Edisi 4). Penerbit ANDI.

Utami, C. W. (2017). Manajemen Ritel Strategi dan Implementasi Operasional Bisnis Ritel Modern di Indonesia (Edisi 3). Salemba Empat.

Widiyati, S., \& Ghozi, S. (2018). Peningkatan Impulse Buying Mahasiswa di Semarang terhadap Produk Fashion Lokal melalui Ethnocentrisme, Brand Image dan Country of Origin (COO). Esensi: Jurnal Bisnis Dan Manajemen, Vol.8(No.1), 4956. https://doi.org/10.15408/ess.v8i1.6979

Wilujeng, S. (2017). Pengaruh Price Discount Dan Bonus Pack Terhadap Impulse Buying Konsumen Indomaret di Kecamatan Sukun Kota Malang. Journal FEB Universitas Kanjuruhan Malang, 457-469.

Zayusman, F., \& Septrizola, W. (2019). Pengaruh Hedonic Shopping Value dan Shopping Lifestyle Terhadap Impulse Buying pada Pelaggan Tokopedia di Kota Padang. Jurnal Kajian Manajemen Dan Wirausaha, Vol.01(No.01), 360-368.

Conflict of InterestStatement:The authorsdeclare that theresearch wasconducted in the absence of any commercial or financial relationships that could be construed as a potential conflict of interest.

Copyright $\odot$ tahun terbit nama belakang and nama belakang. This is an open-access article distributed under the terms of the Creative Commons Attribution License (CC $B Y)$. The use, distribution or reproduction in other forums is permitted, provided the original author(s) and the copyright owner(s) are credited and that the original publication in this journal is cited, in accordance with accepted academic practice. No use, distribution or reproduction is permitted which does not comply with these terms. 


\section{LIST OF FIGURES}

1 Consumer Purchasing Behavior in a Modern Shopping Center .....................................................................2

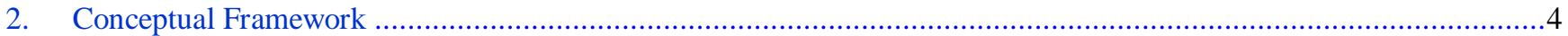

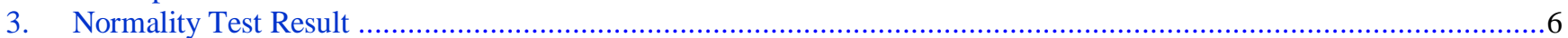

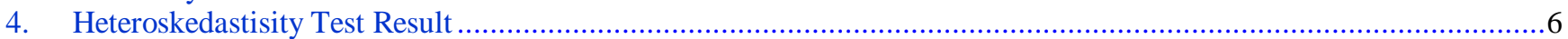




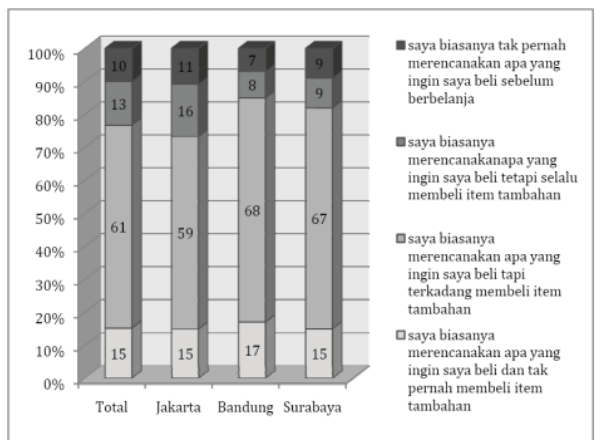

Source: AC Nielsen in Adiputra (2015)

Figure 1 | Consumer Purchasing Behavior in a Modern Shopping Center 


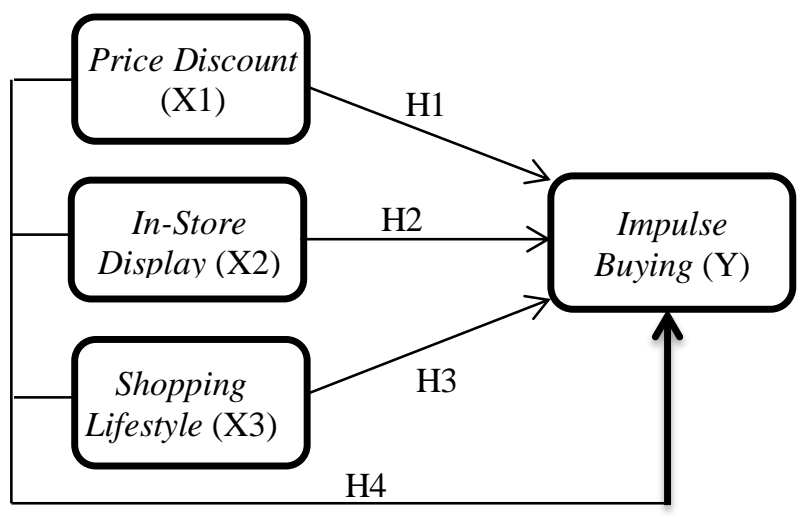

Figure 2| Conceptual Framework 


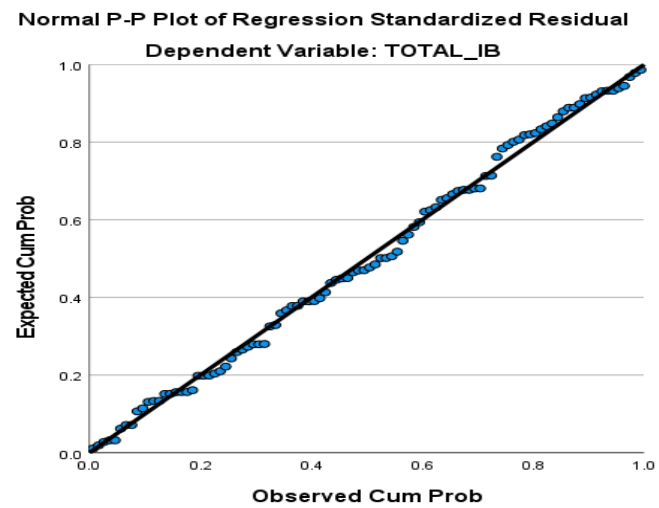

Source: Data processed using IBM SPSS Statistics version 21

Figure 3 | Normality Test Result 


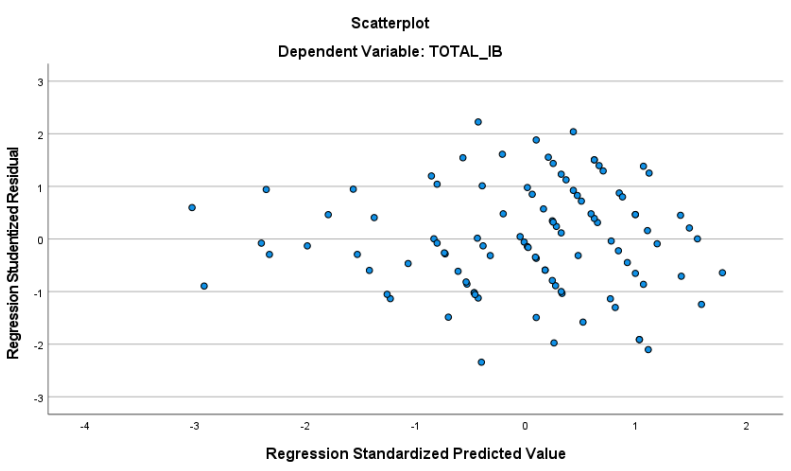

Source: Data processed using IBM SPSS Statistics version

Figure 4 | Heteroskedastisity Test Result 


\section{LIST OF TABLES}

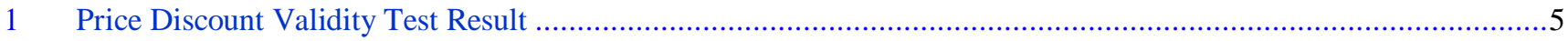

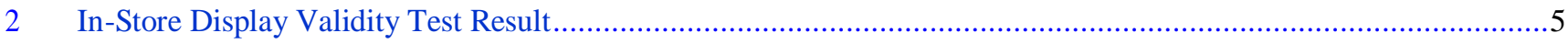

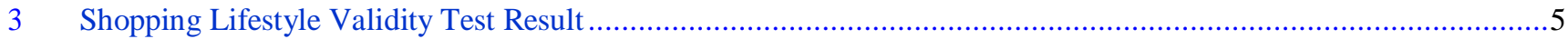

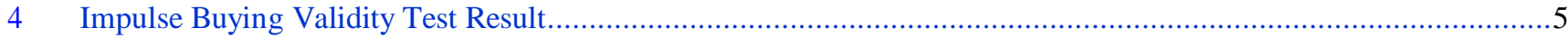

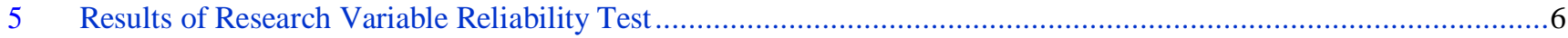

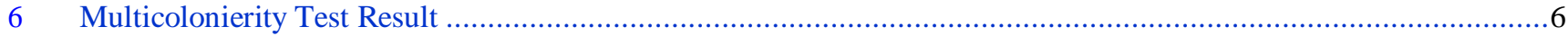

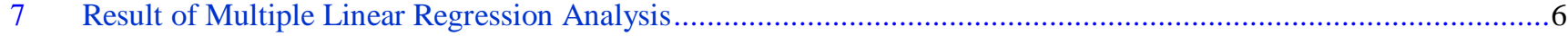

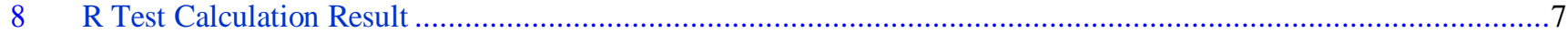

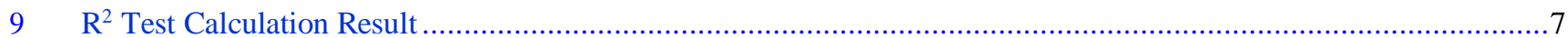

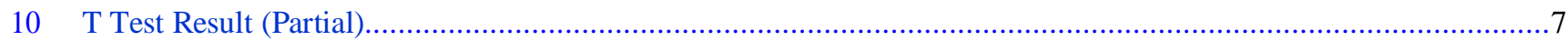

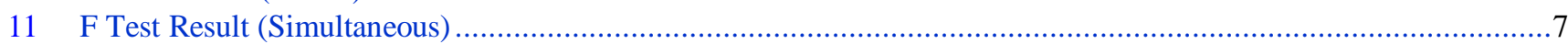


TABLE 1 / Price Discount Validity Test Result

\begin{tabular}{ccccc}
\hline $\begin{array}{c}\text { Statement } \\
\text { Items }\end{array}$ & $\begin{array}{c}\text { Corrected Item Value } \\
\text { Total Correlation / R count }\end{array}$ & Sig. & R Table & Criteria \\
\hline X1.1 & 0,796 & 0,001 & 0,195 & Valid \\
\hline X1.2 & 0,731 & 0,001 & 0,195 & Valid \\
\hline X1.3 & 0,685 & 0,001 & 0,195 & Valid \\
\hline X1.4 & 0,701 & 0,001 & 0,195 & Valid \\
\hline
\end{tabular}

Source : Primary data processed, 2020 
TABLE 2 / In-Store Display Validity Test Result

\begin{tabular}{ccccc}
\hline Statement Items & $\begin{array}{c}\text { Corrected Item Value } \\
\text { Total Correlation / R count }\end{array}$ & Sig. & R Table & Criteria \\
\hline X2.1 & 0,760 & 0,001 & 0,195 & Valid \\
\hline X2.2 & 0,760 & 0,001 & 0,195 & Valid \\
\hline X2.3 & 0,797 & 0,001 & 0,195 & Valid \\
\hline
\end{tabular}

Source : Primary data processed, 2020 
TABLE 3 / Shopping Lifestyle Validity Test Result

\begin{tabular}{ccccc}
\hline Statement Items & $\begin{array}{c}\text { Corrected Item Value } \\
\text { Total Correlation / R count }\end{array}$ & Sig. & R Table & Criteria \\
\hline X3.1 & 0,696 & 0,001 & 0,195 & Valid \\
\hline X3.2 & 0,739 & 0,001 & 0,195 & Valid \\
\hline X3.3 & 0,651 & 0,001 & 0,195 & Valid \\
\hline X3.4 & 0,735 & 0,001 & 0,195 & Valid \\
\hline X3.5 & 0,740 & 0,001 & 0,195 & Valid \\
\hline X3.6 & 0,737 & 0,001 & 0,195 & Valid \\
\hline
\end{tabular}

Source : Primary data processed, 2020 
TABLE 4 / Impulse Buying Validity Test Result

\begin{tabular}{ccccc}
\hline Item Pernyataan & $\begin{array}{c}\text { Nilai Corrected Item } \\
\text { Total Correlation / R hitung }\end{array}$ & Sig. & R Tabel & Kriteria \\
\hline Y.1 & 0,759 & 0,001 & 0,195 & Valid \\
\hline Y.2 & 0,787 & 0,001 & 0,195 & Valid \\
\hline Y.3 & 0,726 & 0,001 & 0,195 & Valid \\
\hline Y.4 & 0,618 & 0,001 & 0,195 & Valid \\
\hline
\end{tabular}

Source : Primary data processed, 2020 
TABLE 5 / Results of Research Variable Reliability Test

\begin{tabular}{cccc}
\hline Variable & Cronbach's Alpha Value & Limit Value & Status \\
\hline Price Discount & 0,707 & 0,60 & Reliabel \\
\hline In-Store Display & 0,662 & 0,60 & Reliabel \\
\hline Shopping Lifestyle & 0,810 & 0,60 & Reliabel \\
\hline Impulse Buying & 0,693 & 0,60 & Reliabel \\
\hline
\end{tabular}

Source : Primary data processed, 2020 
TABLE 6 / Multicolonierity Test Result

\section{Coefficients.}

\begin{tabular}{|c|c|c|c|c|c|c|c|c|}
\hline \multirow{2}{*}{$\frac{\text { Model }}{1}$} & & \multicolumn{2}{|c|}{ Unstandardized Coefficients } & \multirow{2}{*}{$\frac{\text { Standardized Coefficients }}{\text { Beta }}$} & \multirow[t]{2}{*}{$\mathrm{t}$} & \multirow[t]{2}{*}{ Sig. } & \multicolumn{2}{|c|}{ Collinearity Statistics } \\
\hline & & $\mathrm{B}$ & Std. Error & & & & Tolerance & VIF \\
\hline & (Constant) & -1.358 & .708 & & -1.916 & .058 & & \\
\hline & PD & .569 & .007 & .533 & 7.381 & .000 & .223 & 4.475 \\
\hline & ID & .294 & .093 & .187 & 3.171 & .002 & .335 & 2.989 \\
\hline & SL & .183 & .042 & .280 & 4.358 & .000 & .282 & 3.550 \\
\hline
\end{tabular}

Source: Data processed using IBM SPSS Statistics version 21 
TABLE 7 / Result of Multiple Linear Regression Analysis

\begin{tabular}{|c|c|c|c|c|c|c|c|c|}
\hline \multicolumn{9}{|c|}{ Coefficients. } \\
\hline \multirow{2}{*}{$\begin{array}{c}\text { Model } \\
1\end{array}$} & & \multicolumn{2}{|c|}{ Unstandardized Coefficients } & \multirow{2}{*}{$\frac{\text { Standardized Coefficients }}{\text { Beta }}$} & \multirow[t]{2}{*}{$\mathrm{t}$} & \multirow[t]{2}{*}{ Sig. } & \multicolumn{2}{|c|}{ Collinearity Statistics } \\
\hline & & $\mathrm{B}$ & Std. Error & & & & Tolerance & VIF \\
\hline & (Constant) & -1.358 & .708 & & -1.916 & .058 & & \\
\hline & PD & .569 & .007 & .533 & 7.381 & .000 & .223 & 4.475 \\
\hline & ID & .294 & .093 & .187 & 3.171 & .002 & .335 & 2.989 \\
\hline & SL & .183 & .042 & .280 & 4.358 & .000 & .282 & 3.550 \\
\hline
\end{tabular}

a. Dependent Variable: IB

Source: Data processed using IBM SPSS Statistics version 21 
TABLE 8 / R Test Calculation Result

\begin{tabular}{rcrrr}
\hline \multicolumn{7}{l}{ Model Summary } & & \\
\hline \multicolumn{7}{c}{ Model } & $\mathrm{R}$ & $\mathrm{R}$ Square & $\begin{array}{c}\text { Adjusted } \\
\text { R Square }\end{array}$ & $\begin{array}{r}\text { Std. Error of } \\
\text { the Estimate }\end{array}$ \\
\hline 1 & $.942^{\mathrm{a}}$ & .888 & .885 & .905 \\
\hline a. Predictors: (Constant), SL, ID, PD \\
\hline \multicolumn{4}{l}{ b. Dependent Variable: IB } \\
\hline
\end{tabular}


TABLE $9 / \mathbf{R}^{2}$ Test Calculation Result

\begin{tabular}{|c|c|c|c|c|}
\hline \multicolumn{5}{|c|}{ Model Summary } \\
\hline Model & $\mathrm{R}$ & R Square & $\begin{array}{l}\text { Adjusted } \\
\text { R Square }\end{array}$ & $\begin{array}{l}\text { Std. Error of } \\
\text { the Estimate }\end{array}$ \\
\hline 1 & $942^{a}$ & .888 & .885 & .905 \\
\hline \multicolumn{5}{|c|}{ a. Predictors: (Constant), SL, ID, PD } \\
\hline \multicolumn{5}{|c|}{ b. Dependent Variable: IB } \\
\hline
\end{tabular}

Source: Data processed using IBM SPSS Statistics version 21 
TABLE 10 / T Test Result (Partial)

\begin{tabular}{|c|c|c|c|c|c|c|}
\hline \multicolumn{7}{|c|}{ Coefficients. } \\
\hline \multicolumn{2}{|c|}{ Model } & \multicolumn{2}{|c|}{$\begin{array}{c}\text { Unstandardized } \\
\text { Coefficients }\end{array}$} & \multirow{2}{*}{$\begin{array}{l}\text { Standardized } \\
\text { Coefficients } \\
\text { Beta }\end{array}$} & \multirow[t]{2}{*}{$\mathrm{t}$} & \multirow[t]{2}{*}{ Sig. } \\
\hline 1 & & B & $\begin{array}{l}\text { Std. } \\
\text { Error }\end{array}$ & & & \\
\hline & (Constant) & -1.358 & .708 & & -1.916 & .058 \\
\hline & PD & .569 & .007 & .533 & 7.381 & .000 \\
\hline & ID & .294 & .093 & .187 & 3.171 & .002 \\
\hline & SL & .183 & .042 & .280 & 4.358 & .000 \\
\hline
\end{tabular}

Source: Data processed using IBM SPSS Statistics version 21 
TABLE 11 / F Test Result (Simultaneous)

\begin{tabular}{|c|c|c|c|c|c|c|}
\hline \multicolumn{7}{|c|}{ ANOVA } \\
\hline & Model & $\begin{array}{l}\text { Sum of } \\
\text { Squares }\end{array}$ & df & $\begin{array}{c}\text { Mean } \\
\text { Square }\end{array}$ & $\mathrm{F}$ & Sig. \\
\hline \multirow[t]{3}{*}{1} & Regression & 623.587 & 3 & 207.862 & 253.868 & .000 \\
\hline & Residual & 78.603 & 96 & .819 & & \\
\hline & Total & 702.190 & 99 & & & \\
\hline \multicolumn{7}{|c|}{ a. Dependent Variable: IB } \\
\hline \multicolumn{7}{|c|}{ b. Predictors: (Constant), SL, ID, PD } \\
\hline
\end{tabular}

Source: Data processed using IBM SPSS Statistics version 21 